\title{
Aplikasi content language integrated learning (CLIL) \\ berbasis proyek terhadap peningkatan kemampuan \\ berbahasa Inggris mahasiswa
}

\author{
Hery Yufrizal \\ Universitas Lampung \\ Correpondence: heryyufrizal@plasa.com
}

\begin{abstract}
The study aims at evaluating and inventing factors that support or hinder the learning of English through Content Language Integrated Learning Project-Based Approach on English as a subject taught at higher education institutions in Lampung. The resarch is oriented toward product development in which the developmental processes are described in details and the developmental process were described in details. The results showed that Project based CLIL applied at English subject could raun well at some study programs of the Education Faculty of Unila. This is evident from the overall program including the establishmen of student groups. Students worked together in groups to accomplish the project well. Group presentation in English as well as individual presentations showed positive results.
\end{abstract}

Keywords: CLIL, project-based, English, English learning

\begin{abstract}
Abstrak
Penelitian ini bertujuan untuk mengkaji dan menginventarisasi faktorfaktor apa saja yang mendukung atau menghambat pembelajaran Bahasa Inggris melalui Pendekatan Content Language Integrated Learning berbasis projek pada MKU Bahasa Inggris di perguruan tinggi di Lampung. Penelitian ini berorientasi pada pengembangan produk dimana proses pengembangannya dideskripsikan seteliti mungkin dan produk akhirnya dievaluasi. Hasil penelitian menjukukan bahwa program CLIL berbasis projek pada mata kuliah bahasa Inggris di beberapa program studi di FKIP Unila dapat berjalan dengan baik. Hal ini terbukti dari pelaksanaan keseluruhan kegiatan program dari pelaksanaan pembentukan kelompok, mahasiswa bekerja dalam kelompok untuk menyelesaikan proyek dengan baik. Kegiatan presentasi kelompok dalam bahasa Inggris, presentasi pribadi dan tanggapan mahasiswa terhadap semua aktivitas menunjukkan hasil yang positif.
\end{abstract}

Keywords: CLIL, project-based, bahasa Inggris, pembelajaran bahasa Inggris 


\section{Pendahuluan}

Kebutuhan terhadap penguasaan bahasa Inggris di masa mendatang menjadi tantangan tersendiri bagi perguruan tinggi sebagai pencetak tenaga kerja. Kalau mau memenangkan persaingan dalam dunia kerja, perguruan tinggi harus membekali lulusannya dengan kemampuan bahasa Inggris yang memadai. Disamping itu, bagi mahasiswa, memiliki kemampuan berbahasa Inggris yang memadai akan sangat membantu dalam menyelesaikan tugas-tugas kuliah terutama dalam membaca buku-buku teks berbahasa Inggris.

Oleh sebab itu, untuk menjawab semua tantangan di atas diperlukan adanya pembenahan pengajaran bahasa Inggris untuk mahasiswa Program Studi non-bahasa Inggris dengan menggunakan pendekatan perancangan dan pengajaran yang lebih tepat dengan menempatkan kebutuhan pembelajar sebagai isu sentral dalam perancangan pembelajaran. Hal ini sejalan dengan penerapan pendekatan English for Specific Purposes (ESP) dimana pembelajar dan kebutuhannya menjadi pertimbangan utama dalam menentukan proses dan arah pembelajaran sehingga pencapaian tujuan pengajaran dapat berjalan secara efektif dan efisien (Hutchinson \& Waters, 1987; Robinson, 1991) pada era tahun 1990 dan konsep Content Language Integrated Learning (CLIL) pada dekade 2000 sampai sekarang. Tujuan utama pembelajaran dengan pendekatan ini adalah untuk membantu pembelajar agar dapat menguasai bahasa Inggris dalam waktu singkat dan tepat guna sesuai dengan bidang ilmunya (kebutuhannya) masing-masing.

Permasalahan yang mengemuka adalah keterbatasan waktu untuk tatap muka di kelas kerap membuat pembelajaran bahasa Inggris menjadi kurang efektif, terutama untuk kelas dengan tingkat kemampuan berbahasa Inggris yang beragam. Dalam iklim pendidikan tinggi yang menuntut active learning, pengajar bahasa Inggris sering kali kesulitan untuk membantu mahasiswanya yang kompetensi berbahasa Inggrisnya di bawah rata-rata untuk mengejar teman-temannya yang memiliki kompetensi yang mumpuni terlebih umumnya mata kuliah wajib ini hanya diselenggarakan selama satu semester. Padahal, target pembelajaran bahasa Inggris di kampus umumnya cukup tinggi, yaitu menjadikan mahasiswa memiliki kemampuan berbahasa Inggris yang memadai agar mereka dapat menulis tulisan akademik dalam bahasa Inggris sebagai bahasa internasional.

Sebagai upaya untuk memenuhi kebutuhan pembelajaran mahasiswa adalah dengan memanfaatkaan semaksimal mungkin segala potensi yang ada. Misalnya, dengan memanfaatkan perkembangan teknologi informasi memanfaatkan penggunaan internet untuk mengumpulkan bahan ajar berbasis bahasa berdasarkan jurusan atau bidang studi yang ada.

Salah satu langkah yang diambil adalah dengan mengembangkan model pembelajaran Content Language Integrated Learning (CLIL) yaitu dengan 
mengintegrasikan pembelajaran bidang studi dengan pengembangan kemampuan bahasa Inggris. CLIL adalah sebuah pengembangan konsep Englsh for Specific Purposes (ESP), yang berfokus kepada pembelajaran bahasa Inggris untuk tujuan khusus, misalnya untuk bekerja (vocation) atau untuk studi lanjutan (for academic Purposes). Pendekatan CLIL ini dikombinasikan dengan prinsip belajar berbasis proyek karena CLIL murni seharusnya diajarkan oleh dosen bidang studi didampingi oleh Dosen mata kuliah Bahasa Inggris.

Pada penelitian terdahulu (Huzairin, 2018, 2017) dikemukakan bahwa melalui Proyek CLIL yang dilaksanan di Universitas Lampung telah berhasil meningkatkan memampuan berbahasa Inggris mahasiswa. Disamping itu, Penerapan Prinsip CLIL di perguruan tinggi telah berhasil meningkatkan kemampuan mahasiswa memahami teks dalam bahasa Inggris.

Penelitian ini bertujuan:

a. Untuk memproduksin bahan ajar mata kuliah Bahasa Inggris melalui Pendekatan Content Language Integrated Learning berbasis projek padakelancaran dan ketepatan berbahasa Inggris mahasiswa pada MKU Bahasa Inggris di perguruan tinggi di Lampung.

b. Menginventarisasi faktor-faktor apa saja yang mendukung atau menghambat memproduksin bahan ajar mata kuliah Bahasa Inggris melalui Pendekatan Content Language Integrated Learning berbasis projek kelancaran dan ketepatan berbahasa Inggris mahasiswa pada MKU Bahasa Inggris di perguruan tinggi di Lampung.

\section{Kajian pustaka}

\section{Pembelajaran berbasis proyek}

Pembelajaran berbasis proyek adalah sebuah model pengorgansisasian pembelajaran dalam bentuk proyek. Proyek adalah tugas pembelajaran yang kompleks didasarkan atas pertanyaan atau masalah yang menantang yang melibatkan pebelajar dalam merancang, pemecahan masalah, pengambilan keputusan atau kegiatan-kegiatan investigatif, melibatkan pembelajar bekerja secara mandiri untuk batas waktu tertentu dengan tujuan menghasilkan produk yang realistis untuk dipesentasikan (Jones, Rasmussen, \& Moffitt, 1997; Thomas, Mergendoller, \& Michaelson,1999).

Stoller (2006) mendefinsikan pembelajaran berbasis proyek sebagai pembelajaran yang: memiliki target proses dan produk; Memberikan pembelajar hak kepemilikan terhadap proyek; berlangsung selama batas waktu yang cukup panjang (beberapa minggu atau bulan); mengintergrasikan ketrampilan; mengembangkan pemahaman siswa terhadap suatu topik melalui pengintegrasian bahasa dengan subjek ajar lain; berkolaborasi dengan 
mahasiswa lain maupun kerja mandiri; menugaskan peran baru baik kepada mahasiswa maupun guru; membuat siswa menghasilkan produk akhir yang mumpuni; merupakan refleksi proses dan produk.

Pembelajaran Berbasis Proyek merupakan metode belajar yang menggunakan masalah sebagai langkah awal dalam mengumpulkan dan mengintegrasikan pengetahuan baru berdasarkan pengalamannya dalam beraktifitas secara nyata. Pembelajaran Berbasis Proyek dirancang untuk digunakan pada permasalahan komplek yang diperlukan mahasiswa dalam melakukan insvestigasi dan memahaminya.

Pembelajaran Berbasis Proyek memiliki karakteristik sebagai berikut:

1. mahasiswa membuat keputusan tentang sebuah kerangka kerja;

2. adanya permasalahan atau tantangan yang diajukan kepada mahasiswa;

3. mahasiswa mendesain proses untuk menentukan solusi atas permasalahan atau tantangan yang diajukan;

4. mahasiswa secara kolaboratif bertanggungjawab untuk mengakses dan mengelola informasi untuk memecahkan permasalahan;

5. proses evaluasi dijalankan secara kontinyu;

6. mahasiswa secara berkala melakukan refleksi atas aktivitas yang sudah dijalankan;

7. produk akhir aktivitas belajar akan dievaluasi secara kualitatif; dan

8. situasi pembelajaran sangat toleran terhadap kesalahan dan perubahan.

Di dalam pelaksanaannya, model pembelajaran berbasis proyek memiliki langkah-langkah (sintaks) yang menjadi ciri khasnya dan membedakannya dari model pembelajaran lain seperti model pembelajaran penemuan (discovery learning model) dan model pembelajaran berdasarkan masalah (problem based learning model). Adapun langkah-langkah itu adalah; (1) menentukan pertanyaan dasar; (2) membuat desain proyek; (3) menyusun penjadwalan; (4) memonitor kemajuan proyek; (5) penilaian hasil; (6) evaluasi pengalaman. Model pembelajaran berbasis proyek selalu dimulai dengan menemukan apa sebenarnya pertanyaan mendasar, yang nantinya akan menjadi dasar untuk memberikan tugas proyek bagi siswa (melakukan aktivitas). Tentu saja topik yang dipakai harus pula berhubungan dengan dunia nyata. Selanjutnya dengan dibantu dosen, kelompok-kelompok mahasiswa akan merancang aktivitas yang akan dilakukan pada proyek mereka masing-masing. Semakin besar keterlibatan dan ide-ide mahasiswa (kelompok mahasiswa) yang digunakan dalam proyek itu, akan semakin besar pula rasa memiliki mereka terhadap 
proyek tersebut. Selanjutnya, dosen dan mahasiswa menentukan batasan waktu yang diberikan dalam penyelesaian tugas (aktivitas) proyek mereka.

Pembelajaran Berbasis Proyek ini menuntut mahasiswa untuk mengembangkan keterampilan seperti kolaborasi dan refleksi. Menurut studi penelitian, Pembelajaran Berbasis Proyek membantu mahasiswa untuk meningkatkan keterampilan sosial mereka, sering menyebabkan absensi berkurang dan lebih sedikit masalah disiplin di kelas. Mahasiswa juga menjadi lebih percaya diri berbicara dengan kelompok orang, termasuk orang dewasa.

Pelajaran berbasis proyek juga meningkatkan antusiasme untuk belajar. Ketika mahasiswa bersemangat dan antusias tentang apa yang mereka pelajari, mereka sering mendapatkan lebih banyak terlibat dalam subjek dan kemudian memperluas minat mereka untuk mata pelajaran lainnya. Antusias mahasiswa cenderung untuk mempertahankan apa yang mereka pelajari, bukan melupakannya secepat mereka telah lulus tes.

Berdasarkan bagan di atas, kegiatan yang harus dilakukan pada setiap langkah PBP adalah sebagai berikut: a. Penentuan proyek. Pada langkah ini, mahasiswa menentukan tema/topik proyek berdasarkan tugas proyek yang diberikan oleh dosen. Mahasiswa diberi kesempatan untuk memilih/menentukan proyek yang akan dikerjakannya baik secara kelompok ataupun mandiri dengan catatan tidak menyimpang dari tugas yang diberikan dosen. b. Perancangan langkah-langkah penyelesaian proyek Mahasiswa merancang langkah-langkah kegiatan penyelesaian proyek dari awal sampai akhir beserta pengelolaannya. Kegiatan perancangan proyek ini berisi aturan main dalam pelaksanaan tugas proyek, pemilihan aktivitas yang dapat mendukung tugas proyek, pengintegrasian berbagai kemungkinan penyelesaian tugas proyek, perencanaan sumber/bahan/alat yang dapat mendukung penyelesaian tugas proyek, dan kerja sama antar anggota kelompok. c. Penyusunan jadwal pelaksanaan proyek Mahasiswa di bawah pendampingan dosen melakukan penjadwalan semua kegiatan yang telah dirancangnya. Berapa lama proyek itu harus diselesaikan tahap demi tahap. d. Penyelesaian proyek dengan fasilitasi dan monitoring dosen Langkah ini merupakan langkah pengimplementasian rancangan proyek yang telah dibuat. Aktivitas yang dapat dilakukan dalam kegiatan proyek di antaranya adalah dengan a) membaca, b) meneliti, c) observasi, d) interviu, e) merekam, f) berkarya seni, g) mengunjungi objek proyek, atau h) akses internet. Dosen bertanggung jawab memonitor aktivitas mahasiswa dalam melakukan tugas proyek mulai proses hingga penyelesaian proyek. Pada kegiatan monitoring, dosen membuat rubrik yang akan dapat merekam aktivitas mahasiswa dalam menyelesaikan tugas proyek. e. Penyusunan laporan dan presentasi/publikasi hasil proyek Hasil proyek dalam bentuk produk, baik itu berupa produk karya tulis, karya seni, atau karya 
teknologi/prakarya dipresentasikan dan/atau dipublikasikan kepada mahasiswa yang lain dan dosen atau masyarakat dalam bentuk pameran produk pembelajaran. f. Evaluasi proses dan hasil proyek Dosen dan mahasiswa pada akhir proses pembelajaran melakukan refleksi terhadap aktivitas dan hasil tugas proyek. Proses refleksi pada tugas proyek dapat dilakukan secara individu maupun kelompok. Pada tahap evaluasi, mahasiswa diberi kesempatan mengemukakan pengalamannya selama menyelesaikan tugas proyek yang berkembang dengan diskusi untuk memperbaiki kinerja selama menyelesaikan tugas proyek. Pada tahap ini juga dilakukan umpan balik terhadap proses dan produk yang telah dihasilkan.

\section{Penilaian dalam model pembelajaran berbasis proyek}

Karena pembelajaran berbasis proyek dapat memberikan hasil belajar dalam bentuk pengetahuan (knowledge), keterampilan (skill atau psikomotor), dan sikap (attitude atau afektif), maka penilaiannyapun dilakukan untuk ketiga ranah ini. Bentuk penilaian dapat berupa tes atau nontes. Sebaiknya penilaian yang dilakukan untuk model pembelajaran berbasis proyek ini lebih mengutamakan aspek kemampuan mahasiswa dalam mengelola aktivitasaktivitas mereka dalam penyelesaian proyek yang dipilih dan dirancangnya, relevansi atau kesesuaian proyek dengan topik pembelajaran yang sedang dipelajari hingga keaslian (orisinalitas) proyek yang mereka garap.

1. Mahasiswa harus diberikan pemahaman tentang cara berpikir yang mendalam, sistematis, radikal dan universal tentang bidang ilmu yang ditekuni.

2. Mahasiswa lebih banyak merealisir konsep pemikiran menjadi realitas dan berpikir realistis, dengan berbagai contoh.

3. Mahasiswsa harus diberikan tugas yang mampu memacu mereka untuk berpikir realistik dan mewujudkannya dalam bentuk tulisan.

4. Mahasiswa harus dipicu untuk lebih banyak bertanya, yang berangkat dari ketidaktahuan dan keraguan untuk mengembangkan permasalahan utamanya di bidang pendidikan.

\section{Metode}

Penelitian ini mengimplementasikan metode penelitian pengembangan (Developmental Research). Penelitian ini berorientasi pada pengembangan produk dimana proses pengembangannya dideskripsikan seteliti mungkin dan produk akhirnya dievaluasi. Di dalam pembelajaran bahasa Inggris, penelitian pengembangan ini diterapkan dalam aktivitas berulang dari pendesainan dan pengujian terhadap produk material pembelajaran (Gravemeijer, 1999). Hasil 
penelitian ini berupa produk yang berkualitas secara teoritis, prosedural metodologis, dan empiris.

Penelitian dan pengembangan adalah suatu strategi untuk mengembangkan produk pendidikan yang efektif. Penelitian dan pengembangan pendidikan merupakan industri berbasis pengembangan model dimana penemuan-penemuan penelitian digunakan untuk mengembangkan produk dan prosedur baru yang kemudian secara sistematik dilakukan uji lapangan, evaluasi, dan revisi sampai diperoleh atau dicapai kriteria efektifitas dan kualitas tertentu atau mencari standar tertentu (Gall, Gall and Borg, 2003). Langkah-langkah dari proses pengembangan merujuk pada siklus penelitian dan pengembangan yang terdiri dari mempelajari penemuan-penemuan penelitian yang berhubungan dengan produk yang akan dikembangkan, mengembangkan produk berdasarkan kepada penemuan-penemuan penelitian, uji lapangan dengan rancangan seperti keadaan dimana produk akan diterapkan, merivisi produk untuk membetulkan kekurangan-kekurangan yang ditemukan pada langkah uji lapangan. Hal ini karena, menurut Borg (1979), maksud dari penelitian dan pengembangan adalah menjembatani jurang pemisah yang sering ditemui antara penelitian pendidikan dan praktek pendidikan.

Langkah-langkah utama dalam melaksanakan penelitian dan pengembangan pendidikan adalah sebagai berikut.

(1). Studi literatur

(2). Merencanakan

(3). Mengembangkan bentuk produk awal (model teoritis/hipotesis)

(4). Uji lapangan produk awal

(5). Revisi produk awal untuk menghasailkan produk utama

(6). Uji lapangan produk utama

(7) Revisi produk utama untuk menghasilkan produk operasional (model empiris)

(8). Uji lapangan produk operasional

(9). Revisi produksi opersional untuk menghasilkan produk akhir

(10). Diseminasi dan distribusi produk akhir (Gall and Borg dalam

Distrik dkk, 2009).

\section{Teknik Pengumpulan Data}

Dalam pengambilan data, peneliti lakukan melalui dua cara:

a. Studi kepustakaan, hal ini tentu dilakukan untuk memperoleh landasan teoretik yang relevan dan terbaru mengenai prinsip-prinsip content language integrated learning, project based learning, English for 
Academic Purposes, dan pembelajaran bahasa Inggris sebagai bahasa kedua dan bahasa asing.

b. Studi lapangan dilakukan melalui:

1. Observasi lapangan, teknik ini digunakan untuk mengetahui lokasi, pelaku dan kronologis (dinamika pengajaran Bahasa Inggris melalui pendekatan Content Integrated Language Learning dan metode project based learning).

2. Pencarian data otentik, teknik ini peneliti gunakan untuk menemukan fakta-fakta, bukti dan kenyataan dan proses belajar mengajar dimaksud, sehingga dapat dijadikan dasar untuk analisis berikutnya.

3. Wawancara, teknik ini digunakan untuk memperoleh data yang akurat tentang kejadian dan proses dari pelaku. Cara pandang seseorang atau sekelompok orang, baik langsung maupun tidak langsung terlibat dalam proses dimaksud.

4. Kuesioner, diberikan untuk mengkaji tanggapan mahasiswa terhadap pemberian mata kuliah Bahasa Inggris.

\section{Hasil}

\section{Kompetensi bahasa Inggris mahasiswa}

Kompetensi bahasa Inggris mahasiwasiswa diperoleh melalui uji tertulis yang diberikan sebelum dan sesudah pelaksanaan CLIL berbasis proyek. Tabel 1 di bawah ini menggambarkan statistik deskriptif nilai mahasiswa.

Tabel 1. Statistik deskriptif nilai bahasa Inggris (paired samples statistics)

\begin{tabular}{ll|l|l|l|l}
\hline & \multicolumn{1}{|c|}{ Mean } & \multicolumn{2}{|c|}{ N } & \multicolumn{1}{c|}{ Std. Deviation } & \multicolumn{1}{c}{ Std. Error Mean } \\
\hline \multirow{2}{*}{ Pair 1 Pretest } & 57,5794 & 126 & 14,06391 & 1,25291 \\
\cline { 2 - 6 } & postest & 61,1825 & 126 & 13,28964 & 1,18393 \\
\hline
\end{tabular}

Tabel 1 menunjukkan nilai rata-rata mahasiswa pada pretes 57,58 dengan standar deviasi 14,06 dan nilai rata-rata pada postes 61,18 dengan sandar deviasi 13,28 . Untuk mengetahui apakah ada perbedaan yang sigfnifkan anara nilai rata-rata pretest - postest dilakukan uji $\mathrm{T}$ dengan hasil sebagai berikut:

Tabel 2. Hasil uji T pada pretes-postes (one-sample test) 


\begin{tabular}{lllllll}
\hline & & \multicolumn{5}{c}{ Test Value $=0$} \\
& \multirow{2}{*}{$\mathrm{t}$} & Df & Sig. (2-tailed) & $\begin{array}{c}\text { Mean } \\
\text { Difference }\end{array}$ & \multicolumn{2}{c}{$\begin{array}{c}\text { 95\% Confidence Interval of the } \\
\text { Difference }\end{array}$} \\
\cline { 3 - 7 } & & & & Lower & Upper \\
\hline Pretest & 105,408 & 87 & ,000 & 70,37500 & 69,0480 & 71,7020 \\
\hline Postest & 115,137 & 87 & ,000 & 73,54545 & 72,2758 & 74,8151 \\
\hline
\end{tabular}

Tabel 2 menunjukkan perbandingan antara nilai uji kemampuan bahas inggris mahasiswa sebelum dan sesudah pelaksanaan CLIL berbasis projek..Uji $\mathrm{T}$ menunjukkan nilai $\mathrm{T}$ pada pretes sebesar 105,408 dan pda postes sebesar 115,137. Perbedaan kedua nilai itu signifikan paada level o,o01. Hal ini berarti ada perbedaan yang signifikan antara kemampuan atau kompetensi mahasiswa program studi sejarah, ekonomi dan biologi FKIP Unila sebelum dan sesudah pelaksaanaan CLIL berbasis proyek.

\section{Perbandingan nilai antar program studi}

Sebagaimana ditegaskan pada bagian terdahulu bahwa kelas dibagi menjadi kelas eksperimen 1, kelas eksperimen 2, dan kelas kontrol. Tabel 3 di bawah ini menggambarkan statistik deskriptif nilai bahasa Inggris kelas eksperiment dan kelas kontrol.

Tabel 3. Statistik deskriptif nilai pre test dan post test pada kelas eksperimen dan control

\begin{tabular}{|c|c|c|c|c|c|c|c|}
\hline & & $\mathrm{N}$ & Mean & Std. Deviation & Std. Error & Minimum & Maximum \\
\hline \multirow{4}{*}{ pretes } & 1,00 & 40 & 46,3750 & 12,27294 & 1,94052 & 22,50 & 70,00 \\
\hline & 2,00 & 40 & 59,1875 & 14,13519 & 2,23497 & 32,50 & 80,00 \\
\hline & 3,00 & 46 & 65,9239 & 7,78814 & 1,14830 & 45,00 & 77,50 \\
\hline & Total & 126 & 57,5794 & 14,06391 & 1,25291 & 22,50 & 80,00 \\
\hline \multirow{4}{*}{ postes } & 1,00 & 40 & 51,3500 & 11,35793 & 1,79585 & 30,00 & 72,00 \\
\hline & 2,00 & 40 & 63,9750 & 13,16267 & 2,08120 & 40,00 & 85,00 \\
\hline & 3,00 & 46 & 67,3043 & 9,87223 & 1,45558 & 45,00 & 78,00 \\
\hline & Total & 126 & 61,1825 & 13,28964 & 1,18393 & 30,00 & 85,00 \\
\hline
\end{tabular}

Note: 1 = kelas kontrol, 2 = kelas eksperimen 1, 3 = kelas eksperimen 2

Tabel 3 menunjukkan statistik nilai pretes dan postes pada kelas kontrol dan kelas ekperimen. Pada nilai pre tes untuk kelas kontrol nilai rata-rata 46,37 dengan $s d=12,27$. Untuk kelas eksperimen 1 nilai rata-rata 59,18 dengan sd= 14,13. Untuk kelas eksperimen2 nilai rata-rata $65,92 \mathrm{sd}=14,06$. Sedangkan untuk nilai postest, untuk kelas kontrol nilai rata-rata 51,35. Untuk kelas eksperimen1 nilai rata-rata $63,97 \mathrm{sd}=13,16$. Untuk kelas eksperimen2 nilai rata-rata $67,30 \mathrm{sd}=9,87$. 
Tabel 4 berikut ini menggambarkan hasil analisis varian ANOVA antara kelas kontrol dan kelas eksperimen pada pre test and post test.

Tabel 4. Hasil ANOVA nilai pre tes dan postes pada kelas kontrol dan kelas eksperimen

\begin{tabular}{ccccccc}
\hline & & $\begin{array}{c}\text { Sum of } \\
\text { Squares }\end{array}$ & Df & Mean Square & F & Sig. \\
\hline \multirow{3}{*}{ Pretes } & Between Groups & 8328,004 & 2 & 4164,002 & 31,237 & , O0O \\
\cline { 2 - 7 } & Within Groups & 16396,202 & 123 & 133,302 & & \\
\cline { 2 - 7 } & Total & 24724,206 & 125 & & & \\
\hline \multirow{3}{*}{ Postes } & Between Groups & 5902,987 & 2 & 2951,494 & 22,446 & , O0O \\
\cline { 2 - 7 } & Within Groups & 16173,814 & 123 & 131,494 & & \\
\cline { 2 - 7 } & Total & 22076,802 & 125 & & & \\
\hline
\end{tabular}

Dari Tabel 4 diketahui nilai $\mathrm{F}$ hitung 31,25 pada signifikansi o,oo1. Dengan demikian ada perbedaan yang signifikan antara nilai rata-rata mahasiswa di kelas kontrol dan kelas ekpserimental. Begitupun pada hasil nilai post tes ada perbedaan yang signifikan antara nilai rata-rata bahasa Inggris pada kelas kontrol dan eksperimen ( $\mathrm{F}$ hitung $=22,46$ ), pada tingkat signifikansi 0,0001.

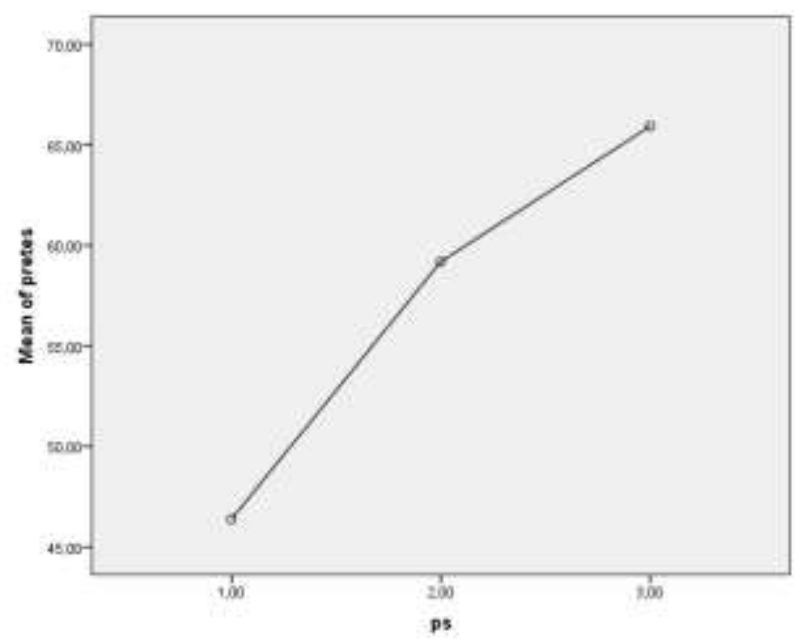

Gambar 1. Perbandingan nilai rata-rata pretes pada kelas kontrol dan kelas eksperimen (ps 1 = kelas kontrol, 2 = kelas eksperimental 1, 3 = kelas eksperimen 2)

Pada Gambar 1 dapat dilihat bahwa nilai rata-rata tertinggi diperoleh oleh mahasiswa pada kelas eksperimental 1, diikuti oleh mahasiswa pada kelas eksperimen 2. Sedangkan nilai rata-rata terendah diperoleh mahasiswa kelas kontrol. 


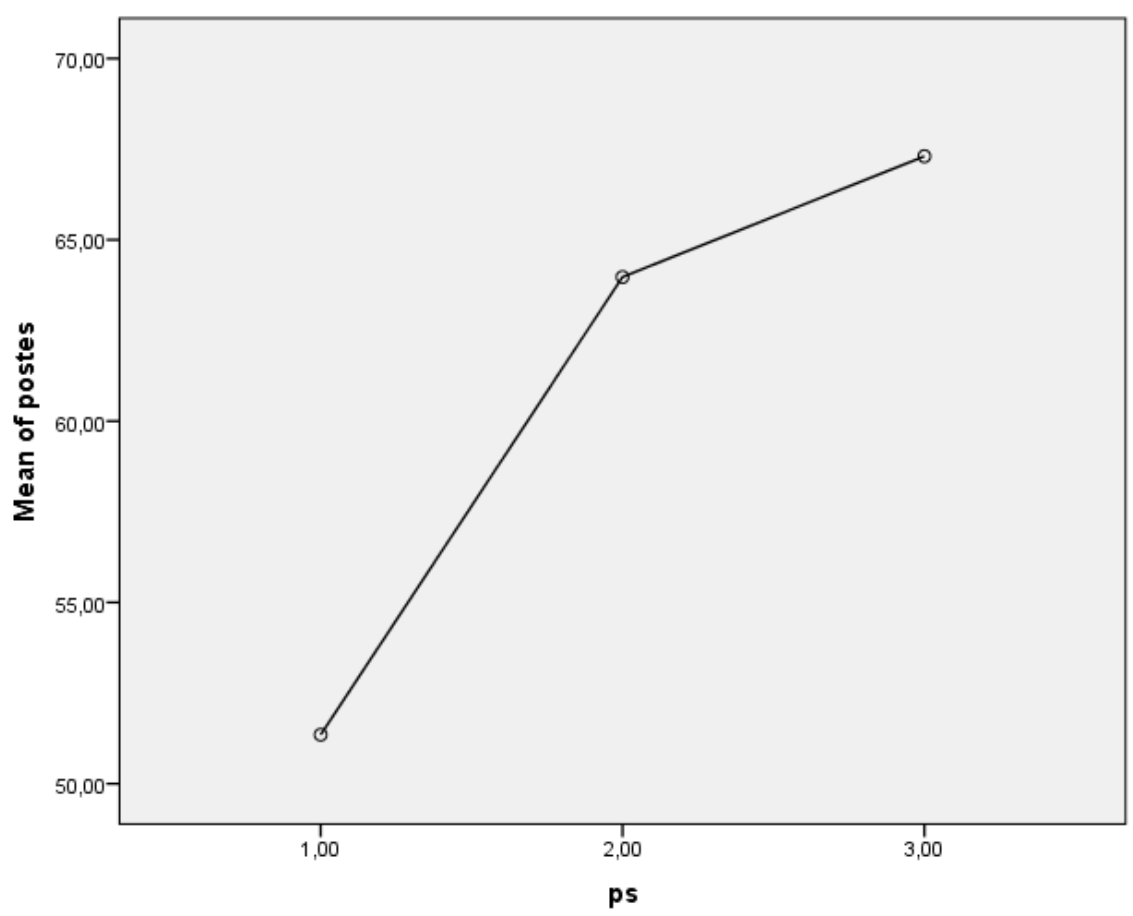

Gambar 2. Perbandingan nilai rata-rata postes pada kelas kontrol dan kelas eksperimental ( 1 = kelas kontrol, 2 = kelas eksperimental 1, $3=$ kelas eksperimen

2)

Gambar 2 menggambarkan nilai rata-rata pada postest kemampuan kebahasaan. Nilai rata-rata tertinggi diperoleh oleh mahasiwa pada kelas eksperimen1, diikuti oleh mahasiwa pada kelas eksperimen 2. Nilai rata-rata terendah diperoleh mahasiswa dari kelas kontrol.

\section{Performansi mahasiswa}

Performansi mahasiswa adalah kemampuan mahasiswa mengemukakan pemikirannya dalam bahasa Inggris secara lisan. Kemampuan lisan mahasiswa tersebut menyangkut aspek: pronunciation, grammar, vocabulary, kelancaran (fluency), dan keterpahaman (comprehensibility). Kelima aspek tersebut terangkum menjadi kemampuan berbicara menyeluruh (overall).

Tabel 4.5 menggambarkan statistic deskriptif kemampuan mahasiswa mengemukakan pemikirannya dalam bahasa Inggris dari kemampuan awal (pretes)

Tabel 5. Statistik deskriptif performansi lisan mahasiswa nilai pre tes

\begin{tabular}{cccccc}
\hline & $\mathrm{N}$ & Minimum & Maximum & Mean & Std. Deviation \\
\hline grammar1 & 126 & 54,00 & 76,00 & 64,9841 & 6,45103 \\
\hline Fluency1 & 126 & 50,00 & 75,00 & 65,3016 & 5,39076 \\
\hline
\end{tabular}




\begin{tabular}{cccccc} 
Pron1 & 126 & 45,00 & 75,00 & 65,1746 & 5,95191 \\
\hline Vocab1 & 126 & 50,00 & 74,00 & 66,2143 & 5,48833 \\
\hline Compre1 & 126 & 45,00 & 75,00 & 67,0000 & 7,15206 \\
\hline Total1 & 126 & 55,20 & 74,40 & 65,7349 & 5,21535 \\
\hline Valid N (listwise) & 126 & & &
\end{tabular}

Dari hasil uji performansi lisan bahasa Inggris mahasiswa diketahui bahwa untuk aspek pronunciation nilai terendah adalah 45,00 dan nilai tertinggi 75 . Sedangkan nilai rata-ratanya $65,17 \mathrm{sd}=5,85$. Untuk aspek vocabulary, nilai terendah 50 dan nilai tertinggi 75 . Sedangkn nilai rata-arata $64,98, \mathrm{sd}=5,39$. Untuk aspek grammar nilai terendah 54 dan nilai tertinggi 76 dengan nilai rata-rata 64,98 . Untuk aspek kelancaran (fluency), nilai terendah 50 dan nillai tertinggi 75 dengan nilai rata-rata $65,30 \mathrm{sd}=5,39$. Untuk aspek keterpahaman (comprehensibility), nilai terendah 45 dan nilai tertinggi 75 dengan nilai rata-rata 67,00, sd $=7,15$.

Secara keseluruhaan kemampuan lisan rata-rata yang diperoleh mahasiswa adalah sebesar $65,73, \mathrm{sd}=5,21$. Ini berarti rata-rata kemampuan lisan mahasiswa PS sejarah, pendidikan ekonomi, dan pendidikan biologi FKIP Unila sebelum diberi tindakan pembelajaran CLIL berbasis projek sudah cukup tinggi.

Tabel 6. menggambarkan statistik deskriptif kemampuan mahasiswa mengemukakan pemikirannya dalam bahasa Inggris dari kemampuan akhir (postes).

Tabel 6. Statistik deskriptif performansi lisan mahasiswa nilai postes

\begin{tabular}{cccccc}
\hline & $\mathrm{N}$ & Minimum & Maximum & Mean & Std. Deviation \\
\hline grammar2 & 126 & 60,00 & 78,00 & 70,8968 & 4,79304 \\
\hline Fluency2 & 126 & 60,00 & 78,00 & 70,8889 & 3,51732 \\
\hline Pron2 & 126 & 56,00 & 78,00 & 71,6429 & 3,54731 \\
\hline Vocab2 & 126 & 65,00 & 80,00 & 72,5159 & 3,18178 \\
\hline compre2 & 126 & 56,00 & 79,00 & 73,6508 & 3,57618 \\
\hline Total2 & 126 & 66,60 & 76,80 & 71,9190 & 1,99843 \\
\hline Valid N (listwise) & 126 & & &
\end{tabular}

Dari hasil uji kompeteni lisan bahasa Inggris mahasiswa diketahui bahwa untuk aspek pronunciation nilai terendah adalah 56 dan nilai tertinggi 78 . Sedangkan nilai rata-ratanya $71,64 \mathrm{sd}=3,51$. Untuk aspek vocabulary, nilai terendah 65 dan nilai tertinggi 8o. Sedangkan nilai rata-arata $72,51 \mathrm{sd}=3,18$. Untuk aspek grammar nilai terendah 60 dan nilai tertinggi 78 dengan nilai rata-rata 70,89. Untuk aspek kelancaran (fluency), nilai terendah 60 dan nilai tertinggi 78 dengan nilai rata-rata $70,88 \mathrm{sd}=3,51$. Untuk aspek keterpahaman (comprehensibility), nilai terendah 56 dan nilai tertinggi 79 dengan nili rata- 
rata $73,65, \mathrm{sd}=3,57$. Secara keseluruhaan kemampuan lisan rata-rata yang diperoleh mahasiswa adalah sebesar 71,91, $\mathrm{sd}=1,99$.

\section{Pembahasan}

Dari hasil penelitian ada beberapa temuan yang terpenting antara lain: program CLIL berbasis projek pada mata kuliah bahasa Inggris Perguruan tinggi Darma Jayya dapat berjalan dengan baik. Hal ini terbukti dari pelaksanaan keseluruhan kegiatan program dari pelaksanaan pembentukan kelompok, mahasiswa bekerja dalam kelompok untuk menyelesaikan proyek dengan baik. Kegiatan presentasi kelompok dalam bahasa Inggris, presentasi pribadi dan tanggapan mahasiswa terhadap semua aktivitas. Hal ini sejalan dengan pendapat Mangubhai (2000) yang menyatakan bahwa pengajaran bahasa perendaman (menggabungkan bahasa dengan subjek lain) adalah 'salah satu pendekatan pembelajaran terbaik. (2000, hal 203). Hal lain yang didapat dari penelitian ini adalah pembelajaran berorientasi produk dan pembelajaran berorientasi proses. Pembelajaran berorientasi produk umumnya didasarkan pada teori psikologis Behaviorisme, berdasarkan eksperimen klasik Pavlov, karya Thorndike dalam mempelajari, dan studi Watson dan Rayner yang menerapkan prinsip Pavlov pada gangguan psikologis. Dan karya Skinner dianggap sebagai referensi penting di bidang ini dan aplikasinya dalam pendidikan (Joyce, Weil, \& Calhoun, 2000, hlm. 318).

Dalam pengajaran bahasa, model pembelajaran dalam kelompok ini umumnya memiliki karakteristik yang diminta Krashen (1981) "belajar", seperti terikat oleh prosedur formal, berorientasi produk / penampilan, dan diurutkan menurut tatabahasa urutan. Peran guru sangat dominan dalam menentukan arah dan prosedur pembelajaran. Peran ini sangat menonjol dalam aktivitas tuban dan substitusi yang paling lazim dalam pendekatan ini. Di antara pendekatan yang paling populer dalam kelompok ini adalah Audiolingual Approach. Pendekatan berpidato berakar dari dua aliran pemikiran yang sejajar di bidang psikologi dan linguistik. Di bidang psikologi, pendekatan ini berakar pada behaviorisme dan neo-behaviorisme, sedangkan di bidang linguistik pendekatan ini berakar pada arus struktural atau deskriptif (Hadley, 2001). Metode pembelajaran yang dihasilkan dari pendekatan ini diberi nama yang sama, metode audio, yang juga dikenal dengan nama berikut: Keterampilan Fungsional, Informasi Kunci Baru, dan Metode Amerika (Benseler \& Schulz, 1980). Berbeda dengan model pembelajaran model pembelajaran yang berorientasi pada produk, model pembelajaran dalam kelompok ini berakar pada pemikiran para teoretikus sosial, yang menekankan sifat sosial manusia, cara manusia mempelajari 
perilaku sosial dan bagaimana interaksi sosial berfungsi. memperkuat keberhasilan pembelajaran akademik (Joyce, Weil, \& Calhoun, 2000). Dalam prakteknya, prinsip-prinsip ini membentuk pengembangan masyarakat belajar kooperatif. Asumsi yang mendasari praktik tersebut telah dirangkum oleh Joyce, Weil, dan Calhoun (2000), yaitu: 1) Sinergi yang dihasilkan dalam pengaturan koperasi menghasilkan motivasi yang lebih kuat daripada yang dihasilkan oleh lingkungan individualistik dan kompetitif. Oleh karena itu, kelompok sosial integratif lebih dari sekadar kumpulan bagiannya. Rasa terhubung menghasilkan energi positif. 2) Anggota kelompok koperasi saling belajar satu sama lain. Setiap siswa mendapat pertolongan lebih banyak daripada dalam memberi hasil kesendirian. 3) Interaksi antar anggota menghasilkan kompleksitas kognitif disamping kompleksitas sosial, menciptakan aktivitas intelektual yang lebih mendukung pembelajaran daripada belajar mandiri. 4) Kerjasama meningkatkan perasaan positif terhadap orang lain, mengurangi keterasingan dan kesepian, membangun hubungan, dan memberikan pandangan yang solid kepada orang lain. 5) Kerjasama meningkatkan citra diri tidak hanya melalui peningkatan pembelajaran tetapi juga melalui rasa dihargai dan diperhatikan oleh orang lain di lingkungan. 6) Siswa dapat merespon pengalaman dalam melakukan tugas yang membutuhkan kerjasama melalui peningkatan keterampilan kerja mereka bersama. Dengan kata lain, semakin besar siswa diberi kesempatan untuk bekerja sama, semakin baik keterampilan mereka dalam bekerja sama. Kemampuan ini membantu kemampuan sosial umum mereka. 7) Siswa, termasuk siswa sekolah dasar, dapat belajar dari praktek untuk meningkatkan keterampilan kerja sama mereka.

\section{Kesimpulan}

Dari uraian hasil dan pembahasannya, dapat disimpulkan bahwa: a) Ada pengaruh yang signifikan terhadap pembelajaran Integrated Language Language yang berbasis proyek terhadap kelancaran dan keakuratan bahasa Inggris mahasiswa Peruruan tinggi Darma Bangsa. Hal ini terbukti dari perbedaan yang signifikan antara kemampuan siswa sebelum dan sesudah mengikuti pembelajaran bahasa Inggris melalui Pembelajaran Terpadu Berbasis Bahasa Berbasis Proyek. b). Tanggapan siswa terhadap pembelajaran bahasa Inggris sebelum dan sesudah Pembelajaran Bahasa Terpadu Berbasis Proyek sangat positif. Hal ini terbukti dari tanggapan siswa terhadap kuesioner (kuesioner) yang diberikan atau tanggapan tertulis siswa dalam bentuk esai. 


\section{Daftar rujukan}

Anderson, L. W., \& Krathwohl, D.R. (Eds). (2001). A taxonomy for learning, teaching, and assessing: A revision of Bloom's taxonomy of educational objectives. New York: Longman.

Bentley, K. (2010). The TKT course CLIL module. Cambridge: Cambridge University Press.

Coyle, D. (2007). Content and language integrated learning: Towards a connected research agenda for CLIL pedagogies. The International Journal of Bilingual Education and Bilingualism, 10, 543-562.

Coyle, D., Hood, P., \& Marsh, D. (2010). CLIL: Content and language integrated learning. Cambridge: Cambridge University Press.

Hadley, A. O. (2001). Teaching Language in Context Third Edition. Boston, MA: Heinle and Heinle Thomson Learning.

Huzairin, Basturi Hasan and Sudirman. 2017. Pengembangan Model Pembelajaran Bahasa Inggris Content And Language Integrated Learning (CLIL) Berbasis Project Mata Kuliah Bahasa Inggris Di Perguruan Tinggi. Laporan Penelitian. Universitas Lampung.

Johnson, D. W., Johnson, R. T., \& Holubec, E. J. (1994). The new circles of learning: cooperation in the classroom and school. Alexandria: Association for Supervision and Curriculum.

Jones, B. F., Rasmussen, C. M., \& Moffitt, M. C. (1997). Real-life problem solving: A collaborative approach to interdisciplinary learning. Washington, DC: American Psychological Association.

Joyce, B., Weil, M. \& Calhoun, E. (2000). Models of Teaching Sixth Edition. Boston: Allyn and Bacon.

Kagan, S. (1992). Cooperative learning. San Juan Capistrano, California: Kagan Cooperative Learning.

Krashen, S. D. (1981). Second language acquisition and second language learning. New York: Pergamon.

Krashen, S. D. (1982). Principles and Practices in Second Language Acquisition. Oxford: Pergamon.

Kumaradivelu, B. (1994). The postmethod condition: (E)merging strategies for second/foreign language teaching. TESOL Quarterly, 28, 27-48

Kumaradivelu, B. (2001). Toward a Postmethod Pedagogy. TESOL Quarterly, $28,27-48$.

Lasagabaster, D. (2008). Foreign language competence in content and language integrated courses. The Open Applied Linguistics Journal, 1, 31-42.

Lasagabaster, D. (2011). English achievement and student motivation in CLIL and EFL settings. Innovation in Language Learning and Teaching 5(1), 3-18.

Lorenzo, F., Casal, S. and Moore, P. (2010). The effects of content and language integrated learning in European education: Key Findings from the Andalusian Bilingual Section. Evaluation Project. Applied Linguistics, 31, 418-442.

Miller, P. C. 2006. Integrating second language into project-based instruction. In project-based learning in second and foreign language education: 
Past, present, and future, ed. G.H. Beckett and P.C. Miller, 225-40. Greenwich, CT: Information Age.

Robinson, R. D., McKenna, M. C., dan Wedman, J. M. (Eds.) (2000). Issues and Trends in Literacy Education Second Edition. Needham Heights, MA: Allyn and Bacon.

Stoller, F. 2006. Establishing a theoretical foundation for projectbased learning in second and foreign language contexts. In Projectbased second and foreign language education: Past, present, and future, ed. G.H. Beckett and P.C. Miller, 19-40. Greenwich, CT: Information Age.

Thomas, J. W. \& Mergendoller, J. R. (2000). Managing project-based learning: Principles from the field. Paper presented at the Annual Meeting of the American Educational Research Association, New Orleans.

Thomas, J. W., Mergendoller, J. R., and Michaelson, A. (1999). Project-based learning: A handbook for middle and high school teachers. Novato, CA: The Buck Institute for Education.

Yufrizal, Huzairin and Hasan. Project based - content language integrated learning (Clil) at Mathematics Department Universitas Lampung. English Language Teaching, 10(9) 